\title{
Severe scleral dellen as an early complication of pterygium excision with simple conjunctival closure and review of the literature
}

\section{"Dellen" escleral grave como complicação precoce de excisão de pterígio com fechamento conjuntival simples e revisão da literatura}

Jose Javier Garcia-Medina ${ }^{1,2,3}$, Mónica del-Rio-Vellosillo ${ }^{4}$, Vicente Zanon-Moreno ${ }^{3,5}$, Amanda Ortiz-Gomariz ${ }^{1}$, Manuela Morcillo-Guardiola ${ }^{1}$, Maria Dolores Pinazo-Duran 3,6

\begin{abstract}
We describe a patient with acute scleral dellen (SD) after pterygium excision with simple conjunctival closure. In addition, we present a PUBMED review on the medical literature on early SD after pterygium surgery. This case describes a 45-year-old man who presented with severe SD, 7 days after pterygium surgery with minimal cauterization of episcleral vessels and simple conjunctival closure. No other adjunctive therapy was used intraoperatively. The patient refused conjunctival flap coverage of the lesion. Therefore, medical treatment consisted of antibiotic ointment, patching, and daily follow-up. After 7 days, the patching was changed for intensive ocular lubrication. Five weeks later, the surrounding conjunctiva had completely covered the affected sclera. To the best of our knowledge, this is the first report of early SD following pterygium excision and simple conjunctival closure with no other adjunctive therapy. When performing pterygium excision with conjunctival coverage of the sclera, a close follow-up is recommended to rule out wound dehiscence and SD, even when surgical wound closure is considered to prevent SD. If this complication is detected, the treatment can be conservative.
\end{abstract}

Keywords: Pterygium/surgery; Gentamicins; Scleral diseases/etiology; Case reports

\section{RESUMO}

Descrevemos um paciente com "dellen" escleral agudo (SD) após excisão de pterígio com fechamento conjuntival simples. Uma revisão adicional da literatura médica sobre SD precoce após a cirurgia de pterígio também é realizada. Este caso descreve um homem de 45 anos de idade, que apresentou SD grave, sete dias após a cirurgia de pterígio com cauterização mínima de vasos episclerais e fechamento conjuntival simples. Nenhuma outra terapia adjuvante foi utilizada no intraoperatório. O pacienterecusou-se à cobertura de retal ho conjuntival da lesão. Portanto, o tratamento médico consistiu em pomada antibiótica, oclusão e acompanhamento diário. Após sete dias, a oclusão foi mudada para a lubrificação ocular intensiva. Cinco semanas após, a conjuntiva cobriu completamente a esclera afetada. Ao melhor de nosso conhecimento, este é o primeiro relato de SD precoce após a excisão do pterígio e fechamento conjuntival simples com nenhuma outra terapia adjuvante. Ao realizar a excisão do pterígio com cobertura conjuntival da esclera, um acompanhamento frequente é recomendado para descartar a deiscência da ferida e SD. Se esta complicação for detectada, o tratamento pode ser conservador.

Descritores: Pterígio/cirurgia; Gentamicinas; Doenças da esclera/etiologia; Relatos de casos

\section{INTRODUCTION}

Several surgical techniques are available for treating pterygium, such as bare sclera, simple conjunctival closure, sliding conjunctival flaps, and conjunctival autografts. Adjunctive therapies, such as postoperative beta radiation or thiotepa drops and intraoperative mitomycin C, can be used to prevent the recurrence of pterygium ${ }^{(1)}$.

Severe scleral dellen (SD) is a rare complication during the early postoperative period following pterygium surgery. The few reports describing this condition are all related to the bare sclera technique without adjunctive therapy ${ }^{(2,3)}$ or with intraoperative mitomycin $C^{(4,5)}$ or beta radiation ${ }^{(6)}$. However, we are unaware of any report of SD associated with pterygium excision followed by minimal cauterization of episcleral vessels and simple conjunctival closure.

\section{CASE REPORT}

A 45-year-old bricklayer with a primary pterygium on the nasal side of his right eye underwent surgical excision with minimal cauterization of episcleral vessels and simple conjunctival closure with two stitches (7/0 silk). The procedure was carried out under topical and subconjunctival anesthesia (lidocaine 2\% and epinephrine 1/200.000). No adjunctive therapy was used intraoperatively. Dexamethasone $(0.5 \mathrm{mg} / \mathrm{g})$ and chloramphenicol $(10 \mathrm{mg} / \mathrm{g})$ ointment were applied and the eye was patched. His medical and ocular histories were unremarkable. The day following surgery, the outcome looked favorable; there was a nasal corneal epithelial defect and the edges of the conjunctival incision were in close apposition with no signs of infection or excessive inflammation. Topical steroids, antibiotics, and artificial tears were prescribed.
Submitted for publication: August 2, 2013

Accepted for publication: December 17, 2013

Study conducted at Department of Ophthalmology, General University Hospital Reina Sofia, Murcia Spain.

Department of Ophthalmology, General University Hospital Reina Sofia, Murcia, Spain

Department of Ophthalmology and Optometry, School of Medicine, University of Murcia, Spain.

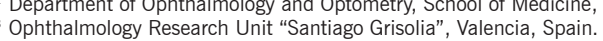

Department of Anesthesia, University Hospital La Arrixaca, Murcia, Spain.

Department of Preventive Medicine \& Public Health, School of Medicine, University of Valencia, Valencia, Spain.

${ }^{6}$ Department of Ophthalmology, School of Medicine, University of Valencia, Valencia, Spain.
Funding: No specific financial support was available for this study.

Disclosure of potential conflicts of interest: None of the authors have any potential conflicts of interest to disclose.

Corresponding author: Jose Javier García-Medina. Department of Ophthalmology. General University Hospital Reina Sofia. Avenida Intendente Jorge Palacios, 1 - 30003 Murcia, Spain E-mail: josegarciam@yahoo.com 
One week later, the patient arrived at the emergency department complaining of moderate pain and a black dot in his right eye. His best corrected visual acuity was 10/10 and intraocular pressure was $15 \mathrm{mmHg}$. Slit lamp examination revealed severe scleral thinning reaching the choroid (Figure 1). The conjunctival sutures were no longer in place. The anterior chamber was deep with no Tyndall effect, whereas the pupils were isocoric and normoreactive. The fundus showed transparent media with no other abnormal findings. The patient refused improper eye handling, therapeutic failure, or going back to work in a dusty environment. Reconstructive surgery through a conjunctival flap was offered, but the patient refused; therefore, a conservative medical treatment was prescribed that included gentamicin antibiotic ointment ( $3 \mathrm{mg} / \mathrm{g}$ ), patching for 7 days, and daily outpatient monitoring, which was followed by intensive ocular lubrication (carmellose $10 \mathrm{mg} / \mathrm{mL}$ every hour) for 6 weeks. Within a few weeks, the conjunctival defect was replaced by granulation tissue, and later with a flap of adjacent conjunctiva. The photographic series illustrates the patient's evolution (Figures 2 and 3).

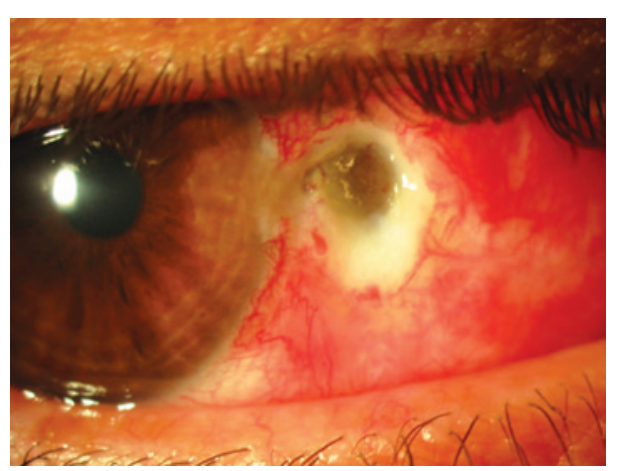

Figure 1. Initial appearance of the scleral dellen reaching the choroid.
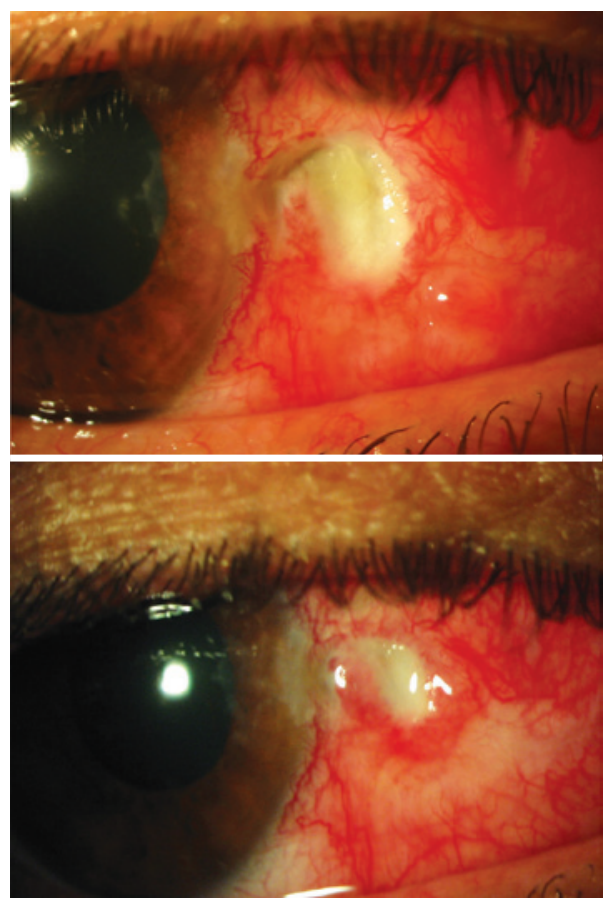

Figure 2. The sclera dellen on day 3 (top) and on day 7 (bottom) from its onset.
After solving the case, the patient was referred to internal medicine to rule out collagen or infectious disease. Medical history, physical examination, and laboratory test (blood count, biochemistry, rheumatoid factor, autoantibody screening, infectious serology, and Mantoux) revealed no infectious or autoimmune inflammatory disease.

\section{DISCUSSION}

As seen above, several surgical techniques can be used to treat pterygium. The bare sclera technique includes excision of the pterygium, which leaves the conjunctival defect to heal by sclera epithelization from the surrounding conjunctiva. Exposing the sclera contributes to drying, and therefore is a risk factor for thinning. All severe scleral thinning cases during the early postoperative period seem to be associated with the bare sclera technique. In our case, however, we used the primary excision technique with simple conjunctival closure (Table 1).

The fact that no stitches were found at about 1 week post-surgery suggests improper eye handling by the patient, excessively lax stitches, or a combination of both. The dehiscence of the wound, possibly resulting in exposure of the underlying sclera and edema, and raised conjunctiva edges, may have caused a discontinuity of the tear film leading to exacerbated local dehydration. In their publication, Chen and Noonan ${ }^{(2)}$ attributed SD after pterygium surgery with the bare sclera technique to raised granulation tissue edges, which developed in the conjunctiva margin of exposed sclera.

Whereas the growth of blood vessels in the wound bed is considered to contribute to pterygium recurrence, some authors have recommended cauterization of episcleral vessels, especially at the limbus. However, it appears that coagulation of the episcleral vessels, which do not bleed, neither avoids recurrences nor contributes to accomplishing better esthetic results during pterygium surgery (personal communication of Lawrence W. Hirst). The cauterization applied to our patient was performed carefully and only with the purpose of avoiding bleeding during surgery. Nonetheless, this factor has to be considered in the etiology of scleral perforation as it may
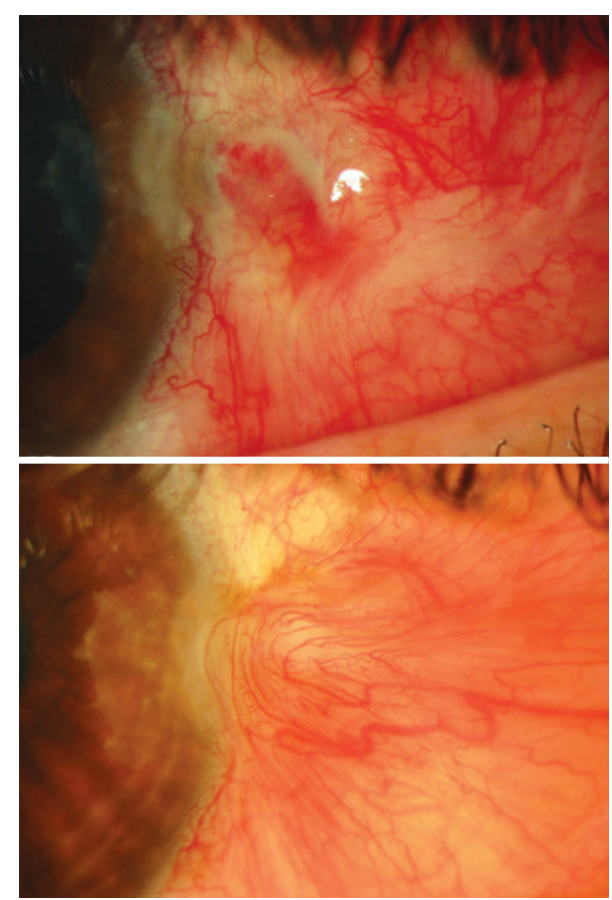

Figure 3. The sclera dellen on day 12 (top) and on day 38 (bottom) from its onset. 
Table 1. Summary of published cases of early scleral dellen after pterygium surgery

\begin{tabular}{|c|c|c|c|c|c|c|}
\hline Reference & $\begin{array}{l}\text { Surgical } \\
\text { technique }\end{array}$ & $\begin{array}{c}\text { Cauterization } \\
\text { of episcleral } \\
\text { vessels }\end{array}$ & $\begin{array}{l}\text { Intraoperative } \\
\text { adjunctive } \\
\text { therapy }\end{array}$ & $\begin{array}{c}\text { Topical } \\
\text { corticosteroids } \\
\text { after surgery }\end{array}$ & $\begin{array}{l}\text { Onset of signs/ } \\
\text { symptoms } \\
\text { (from surgery) }\end{array}$ & Treatment \\
\hline Chen and Noonan ${ }^{(2)}$ & Bare sclera & Minimal & None & Yes & 14 days & Conjunctival flap \\
\hline Mitra et al..$^{(3)}$ & Bare sclera & Unknown & None & Yes & 7 days & Antibiotic and artificial tears \\
\hline Tsai et al. ${ }^{(4)}$ & Bare sclera & Unknown & Mitomycin C & Yes & 8 days & Artificial tears \\
\hline Safianik et al.(5) & Bare sclera & Unknown & Mitomycin C & Unknown & 21 days & Conjunctival flap \\
\hline Hicks et al. ${ }^{(6)}$ & Bare sclera & Unknown & Beta-radiation & Unknown & 2 days & Patching \\
\hline $\begin{array}{l}\text { Garcia-Medina et al. } \\
\text { (present case) }\end{array}$ & $\begin{array}{l}\text { Simple conjunctival } \\
\text { closure }\end{array}$ & Minimal & None & Yes & 7 days & $\begin{array}{c}\text { Patching, antibiotic, and } \\
\text { artificial tears }\end{array}$ \\
\hline
\end{tabular}

cause local ischemia. In the cases reported in the literature, whether episcleral vessel cauterization was used or its duration is unclear. ${ }^{(2-6)}$ Subconjunctival anesthesia containing a vasoconstrictor agent (epinephrine) also may have been a contributory factor for local ischemia in the present case.

Topical corticosteroids enhance collagenases and inhibit collagen synthesis, which may have also contributed to SD formation, as proposed by Mitra et al.(3). Therefore, they should be removed immediately.

The conjunctival flap graft has been used successfully to manage these complications ${ }^{(2,5)}$. As the patient refused this surgical procedure, we had the opportunity to assess the evolution of scleral erosion with medical treatment. We found that eye patching, antibiotic coverage, and intensive lubrication combined are sufficient for healing this complication. Conservative treatment has also been proved to be successful in the cases that other authors have presented ${ }^{(3,4,6)}$.

In conclusion, we can state that pterygium excision with primary conjunctival closure and cauterization of episcleral vessels may result in severe SD, even in patients with no history of risk, as was the case presented here. Conservative treatment may be appropriate to manage this rare complication.

\section{REFERENCES}

1. Hirst LW. The treatment of pterygium. Surv Ophthalmol. 2003;48(2):145-80.

2. Chen S, Noonan C. Scleral dellen complicating primary pterygium excision. Eye. 2000;14(Pt 1):100-1.

3. Mitra S, Ganesh A, Shenoy R. Scleral dellen complicating primary pterygium excision. Eye. 2000;14 (Pt 6):924-5.

4. Tsai YY, Lin JM, Shy JD. Acute scleral thinning after pterygium excision with intraoperative mitomycin C: a case report of scleral dellen after bare sclera technique and review of the literature. Cornea. 2002;21(2):227-9.

5. Safianik B, Ben-Zion I, Garzozi HJ. Serious corneoscleral complications after pterygium excision with mitomycin C. Br J Ophthalmol. 2002;86(3):357-8.

6. Hicks RR, Irvine AR, Spencer WH, Yuhasz Z. Scleral dellen. Arch Ophthalmol. 1975; 93(1):88-9. 